\title{
The Dating of Pheidon In ANTiQuity
}

\author{
Mait Kõiv
}

\section{Introduction}

The dating of the Argive tyrant (or king) Pheidon, a central figure of early Greek history according to the ancients, ${ }^{1}$ has long been one of the most disputed questions in the history of Archaic Greece. The reason is obvious - even in antiquity there was no agreement on this point. According to Herodotos, Pheidon's son Leokedes was among the suitors of Agariste, the daughter of the Sikyonian tyrant Kleisthenes. ${ }^{2}$ Since the wedding must be dated to the $570 \mathrm{~s} \mathrm{BC},{ }^{3}$ this suggests that Pheidon must have lived roughly at the end of the seventh and the beginning of the sixth centuries BC. But all the authors who wrote after Herodotos dated him much earlier. They do, however, make contradictory statements. According to Ephoros, Pheidon was the 10th descendant of Temenos, the Herakleid founder of Dorian Argos. ${ }^{4}$ Since Ephoros dated the invasion of the Herakleids to $1069 \mathrm{BC},{ }^{5}$ counting inclusively 6 and probably equating three generations to a century, ${ }^{7}$ the 10 th generation from Temenos should have fallen somewhere in the eighth century BC, presumably in the years ca. 769736 BC. Ephoros' younger contemporary, Theopompos, on the other hand, regarded Pheidon as Temenos' 6th descendant (inclusively), ${ }^{8}$ which would lead roughly to the first third of the ninth century BC. ${ }^{9}$ Of the later sources, Marmor Parium, considering

\footnotetext{
1 Pheidon was known as a powerful and ambitious ruler who had gathered up the large territorial heritage of his ancestor Temenos, plotted against Corinth and, above all, forcibly invaded Olympia and celebrated the games himself. He was also credited with the establishment of a system of measures and weights and was believed to have been the first to mint silver coins (Hdt. VI, 127; Ephoros FGrH $70 \mathrm{~F}$ 115, 176; Arist. Pol. 1310 b; Marm. Par. FGrH 239, 30; Plut. Mor. 772-773; Orion, Etymologicum, s.v. òßoגós; etc.).

${ }^{2}$ Hdt. VI, 127.

3 M. F. McGregor, Cleisthenes of Sicyon and the Panhellenic Festivals, TAPhA 72, 1941, 276-279; V. Parker, Zur griechischen und vorderasiatischen Chronologie des sechsten Jahrhunderts v. Chr. unter besonderer Berücksichtigung der Kypselidenchronologie, Historia 42, 1993, 397.

${ }^{4}$ FGrH 70 F 115.

5 According to Ephoros the Herakleids invaded Peloponnesos 735 years before the beginning of the campaign of Alexander the Great, thus in 1069 BC (F 223 = Clemens, Strom. I, 193, 3-4).

6 This is demonstrated by F 149 and 173 where Lykourgos was counted as the 6th descendant of Prokles and the 11th from Herakles, which is possible only by inclusive counting.

7 This is demonstrated by Ephoros' use of full centuries: F 102 (Homer dated 100 years before the first Olympic games), but also Nikolaos of Damascus FGrH 90 F 56 (500 years of Spartan eunomia), Diod. XV, 50, 2 (almost 500 years of Spartan hegemony) and Diod. VII, 12 (more than 400 years of Spartan hegemony). Nikolaos and Diodoros probably followed the chronological pattern of Ephoros (see G. Busolt, Griechische Geschichte I, Gotha 1893, 573, n. 8; F. Jacoby, Apollodors Chronik, Philologische Untersuchungen 60, Berlin 1902, 89, n. 13, 115-116; F. Kiechle, Messenische Studien, Kallmuenz 1959, 94, n. 15). Ephoros, like his teacher Isokrates (Archid. 12), probably counted back from the collapse of the Spartan hegemony in Peloponnesos in 370/69 BC (Jacoby op. cit. 115-116), and the 700 years from ca. 370 to 1069 were 21 generations of $331 / 3$ years $(21 \times 331 / 3=700)$. Indeed, there are 21 generations (inclusively) in the Agiad line of the Spartan kings from the Herakleid invader Aristodemos to Kleombrotos who fell in the battle of Leuktra.

${ }^{8}$ FGrH 115 F 393.

9 Aristotle's statement (Pol. 1310b) that the type of tyrants represented by Pheidon is earlier than the tyrants-demagogues, gives the middle of the seventh century as the terminus ante quem for Pheidon and is in keeping with the opinions of both Ephoros and Theopompos.
} 
Pheidon to be the 11th descendant of Herakles (which means that he must have been the 7th descendant of Temenos) and dating him to $895 \mathrm{BC},{ }^{10}$ was fairly close to Theopompos' point of view, while Pausanias, dating Pheidon's intervention and agonothesia at Olympia to Ol.8 (748 BC), conforms to Ephoros' opinion. But we have two other datings which do not at first sight accord with any of the previous statements: the chronicle of Eusebios introduces Pheidon at Abr. 1220, that is, 797 $\mathrm{BC}, 11$ while Isidorus of Sevilla dated him to the time of the first Olympic games in 776 BC. ${ }^{12}$

The variation in the ancient statements has given the moderns a good chance to place Pheidon in whatever historical context they please, proposing ingenious constructions to determine his true date, which has been placed anywhere from the middle of the eighth to the first half of the sixth century BC. ${ }^{13}$ However, in all this they have generally not asked about the reasons that led the ancients to put forward such apparently discrepant datings and how they relate to each other. Obviously, the datings of Pheidon could not have stood apart from the ancient chronological systems. They must all have been part of one system or other. But, curiously enough, the moderns have discussed the dating of Pheidon in isolation, outside the general framework of ancient chronography, while, on the other hand, studies on the formation of the ancient chronological tradition have paid almost no attention to Pheidon's date. ${ }^{14}$ Therefore, the use of the ancient dates for Pheidon has been

${ }^{10}$ FGrH 239 ep. 30.

11 Euseb. Chron. II, 74-75 Schoene.

12 Isidorus, Chronicon 34.

13 One can distinguish (1) the early dating to the eighth century BC (G. F. Unger, Die Zeitverhältnisse Pheidons, Philologus 28-29, 1869-1870; H. Swoboda, Elis. Die Landschaft, RE V, 1905, 2386; J.Wells, Studies in Herodotus, Oxford 1923, 56-58; G. Vitalis, Die Entwicklung der Sage von der Rückkehr der Herakleiden, Greifswald 1930, 19-26; G. L. Huxley, Argos et les derniers Téménides, BCH 82, 1958, 588-601; H. Berve, Die Tyrannis bei den Griechen I, München 1967, 6; E. Manni, Fidone d'Argo, i Bacchiadi di Corintho e le fondazione di Siracusa e di Megara Iblea, Kokalos 20, 1974, 77-91; N. Coldstream, Geometric Greece, London 1977, 154-156; A. Foley, The Argolid in 800-600 BC, Göteborg 1988, 167-168; H.-J. Gehrke, Herodot und die Tyrannenchronologie, Memoria Rerum Veterum, Stuttgart 1990, 38-42; L. de Libero, Die archaische Tyrannis, Stuttgart 1996, 208), (2) the middle dating to the first half and the middle of the seventh century BC $(\mathrm{H}$. Weissenborn, Hellen. Beiträge zur genauere Forschung der griechische Geschichte, Jena 1844, 1-66; Busolt, (n. 1), 611-625; P. N. Ure, The Origin of Tyranny, Cambridge 1922, 155-161; H. T. Wade-Gery, The Growth of the Dorian States, CAH III, Cambridge 1925, 761-762; O. Viedebantt, Forschungen zur altpeloponnesische Geschichte. 1. Der Tyrann Pheidon von Argos, Philologus 81, 1926, 212-214; T. Lenschau, Pheidon, RE XIX 2 (1938), 1941; D. W. Bradeen, The Lelantine war and Pheidon of Argos, TAPhA 78, 1947, 232; A. Andrewes, The Corinthian Actaeon and Pheidon of Argos, CQ 43, 1949, 7477; The Greek Tyranny, Oxford 1956, 39-42; W. Den Boer, Laconian Studies, Amsterdam 1954, 5564; E. Will, Korinthiaca, Paris 1955, 346-351; G. Zörner, Kypselos und Pheidon von Argos, Marburg 1971, 66-67; R. A. Tomlinson, Argos and Argolid, London 1972, 82-83; L. H. Jeffery, Archaic Greece: the City-States c. 700-500 BC, London 1978, 134-136; O. Murray, Early Greece, London 1980, 138; N. G. L. Hammond, The Peloponnese, CAH III 1, Cambridge 1982, 325; T. Figueira, Excursions in Epichoric History: Aiginetan Essays, Rowman \& Littlefield Publishers 1993, 12-16) and (3) the late dating to the end of the seventh and the beginning of the sixth century $\mathrm{BC}$ (C. Trieber, Pheidon von Argos, Historische Aufsätze für Waitz, Hannover 1886, 1-16; K. J. Beloch, Griechische Geschichte I 2, Strassburg 1913; T. Kelly, A History of Argos to 500 BC, Minneapolis 1975, 94-111; R. Drews, Basileus, New Haven and London 1983, 60; P. Carlier, La royauté en Grèce avant Alexandre, Strasbourg 1984, 387-388; P. Barcelo, Basileia, Monarchia, Tyrannis, Stuttgart 1993, 114).

14 Note especially E. Schwartz, Die Königslisten des Eratosthenes und Kastor, Abhandlungen der Gesellschaft der Wissenschaften zu Göttingen, Phil.-hist. Klasse 40, 1894-1895, 1-96; Jacoby (n. 7); A. A. Mosshammer, The Chronicle of Eusebios and Greek Chronographic Tradition, Lewisburg, 
selective. Each scholar has adopted the dates that suit to justify his own conception, while almost no attention has been paid to the statements that could be dismissed as $a$ priori improbable. ${ }^{15}$

But to be able to make any use of the dates provided by the ancient writers one must ask about their position in the general chronological framework and try to discover the data on which they were based. However improbable these dates might seem to us, they were nevertheless based on some information that the ancients had. So they could reveal some basic assumptions of the ancients about Pheidon's historical context and in this way broaden our understanding of what the ancients believed that they knew about him.

Therefore, the purpose of this paper is to investigate the considerations that could have led the ancient chronographers to date Pheidon in the way they did. No straightforward suggestion will be made about the "real" date of the "real" Pheidon. I will also omit from the discussion the statement of Herodotos. Justly or not, the authors from the 4th century BC onwards did not pay any attention to his point of view, proposing instead dates that certainly cannot be reconciled with his statement. They must have had some grounds for this, and these grounds are the subject of this enquiry.

\section{The statements of Ephoros and Pausanias}

As stated above, according to Ephoros, Pheidon was the 10th descendant of Temenos, and so presumably active in the years ca. 769-736 BC, while Pausanias dated his agonothesia at Olympia to O1.8. (748 BC). These statements obviously agree with each other. In principle, one cannot exclude the possibility that Pausanias related the date of Pheidon's agonothesia correctly, according to the Olympian chronicle of Hippias, and that Ephoros expressed the same thing in genealogical terms. ${ }^{16}$ The exact date of Pheidon's agonothesia, and probably also of other events in early Olympian history, must, in that case, have been well known to the Greek historians at least from the late fifth century when Hippias was writing. There could have been no essential disagreement on these points. But ancient evidence on Pheidon's date and the conflicts of the Eleians and the Pisatans over Olympian agonothesia is certainly too divergent to favour such a straightforward solution.

Therefore, the documentary basis of Ephoros' and Pausanias' statements has been given little credit by the moderns. But many of them have still clung to the idea that the correct date of Pheidon's agonothesia was known to the ancients and is to be discovered from the confused accounts of later ancient authorities. Instead of taking Pausanias' date at face value, scholars have often combined his and Ephoros' data with Eusebios' and Apollodoros' accounts of early Olympian history, proposing a construction which leads to the dating of Pheidon's agonothesia to $668 \mathrm{BC}$, while

London 1979; D. Fehling, Die Sieben Weisen und die frühgriechische Chronologie, Bern, Frankfurt am Main, New York 1985). None of these contain any discussion of Pheidon's date.

15 To my knowledge, an attempt to explain all the ancient dates can only be found in Busolt (n. 7), 612-616 (mostly in the footnotes).

16 Ungern (n. 13, 1869), 405; Huxley (n. 13), 593; Jacoby, FGrH II C, 1926, 684; Lehnschau (n. 13), 1941. 
considering the date suggested by Ephoros to be a misconception and that of Pausanias a simple and easily corrected error.

According to Ephoros, ${ }^{17}$ Eleia and Olympia were sacrificed to Zeus at the time of the Herakleid invasion and any armed presence in the district was banned. Subsequently, Iphitos of Elis established the Olympic games. But Pheidon, the 10th descendant of Temenos, forcibly interrupted Eleian domination. He invaded the district and celebrated the games himself, taking advantage of the fact that, because of the sacred peace, the Eleians did not have any arms with which to defend themselves. The Eleians, however, did not record this Olympiad, but obtained arms and with the help of the Spartans brought Pheidon down. In the course of these events Pisatis and Triphylia were also subjected to the Eleians. In other words, Ephoros believed that Pheidon's intervention at Olympia had caused the alliance of Elis and Sparta and that his defeat had brought with it the subjection of Pisatis and Triphylia to Eleian power.

The accounts of Eusebios and Apollodoros did not ascribe the interruption of the Eleian hegemony to Pheidon, as Ephoros did, but considered it instead to be the result of a Pisatan revolt. According to Eusebios ${ }^{18}$ the Pisatans first celebrated the games at O1.28 (668 BC) when the Eleians were occupied in the war against Dyme. Apparently, this Pisatan agonothesia was understood as a peaceful agreement. ${ }^{19}$ But at Ol.30 (660 BC) the Pisatans revolted against the Eleians and presided over the games for the next 22 Olympiads, that is, until O1.52 (572 BC). The account of Apollodoros $^{20}$ is in many respects similar, but dates the events slightly differently. The Pisatans interrupted the continuous chain of Eleian agonothesia after the 26th Olympiad, thus presumably at O1.27 (672 BC), and the Eleian hegemony was

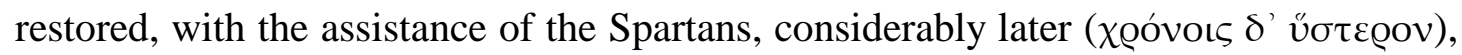

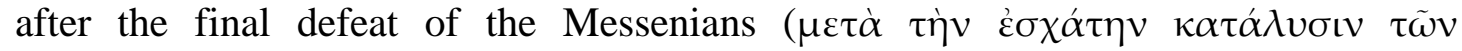

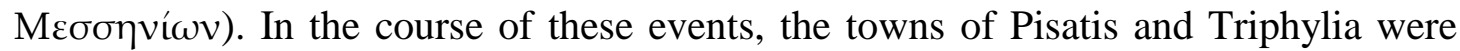
destroyed and the district was finally subjected to the Eleians. Thus, the alliance of Elis and Sparta and the consequent subjection of Pisatis and Triphylia, which, according to Ephoros, resulted from Pheidon's aggression and downfall in the eighth century BC, were, in Apollodoros' version, considered to be the result of the Pisatan interlude that began in $672 \mathrm{BC}$.

However, what all these versions had in common was that there had been one great conflict in early Olympian history. But Pausanias reported several distinct incidents. At Ol.8 (748 BC) Pheidon allied himself with the Pisatans, expelled the Eleians and celebrated the games. Later, at Ol.34 (644 BC), the Pisatan king Pantaleon revolted against the Eleians and celebrated the festival. Next the Pisatans plotted against Elis at Ol.48 (588 BC) under Pantaleon's son Damophon, and thereafter (the exact date is not given) under Damophon's brother Pyrrhos. At this time the inhabitants of the nearby Triphylian towns also rebelled. But the Eleians proved victorious and expelled both

\footnotetext{
17 Strab. VIII, 357-358 = Ephoros FGrH 70 F 115.

18 Euseb. Chron. I, 192 ff. Schoene. Eusebios could have followed here the account of Julius Africanus (but see Mosshammer (n. 14), 146-157).

19 Peaceful relations between the Eleians and the Pisatans are also suggested by Phlegon FGrH 257 F 1 and Schol. Plat. Polit. V 465; see C. Meier, Pisa, RE XX 2, 1950, 1748.

20 Strab. VIII, 354-355. Apollodoros is commonly accepted as the source: E. Schwartz, Apollodoros, RE I, 1894, 2869; Swoboda (n. 13), 2388; Meier (n. 19), 1747; Kiechle (n. 7), 27. Viedebantt (n. 13), 228-231) ascribed the account to Ephoros.
} 
the Pisatans and the other rebels from their homeland. ${ }^{21}$ This seems to have happened, according to Pausanias, before Ol.50 (580 BC), since on this date he mentioned at Olympia the introduction of two hellanodikai instead of the previous one, ${ }^{22}$ which implies a kind of settlement of affairs after the previous troubles.

So we have four different accounts of the early history of the Olympian games. According to Ephoros there was a single intervention by Pheidon, according to Apollodoros and Eusebios a long Pisatan interlude and according to Pausanias, Pheidon's intervention side by side with two later Pisatan interludes. But a certain similarity between these instances is still obvious. An interruption at Olympia, either Pheidon's intervention or a Pisatan revolt, was believed to have brought about the final subjugation of Pisatis and Triphylia to the Eleians. And in both cases the Eleians were believed to have been assisted by the Spartans.

Therefore it has been suggested that Pheidon's interference in Ephoros and the Pisatan interlude in Apollodoros and Eusebios were in fact one and the same incident. Indeed, according to Pausanias, Pheidon was allied with the Pisatans. And since neither Apollodoros nor Eusebios had mentioned any interference at Olympia before 672 BC, which seems to exclude any earlier intervention by Pheidon, he has been dated to the time of the beginning of the Pisatan interlude in the seventh century. ${ }^{23}$ The defeat of Pheidon and his Pisatan allies is, then, to be associated with the second Messenian war in which the Pisatan Pantaleon was, according to Apollodoros, one of the

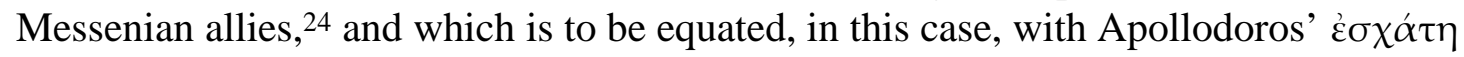


Pheidon to Ol.8 has been considered to be the result of a transcription error that should be corrected to Ol.28 (668 BC), the date of the first Pisatan celebration at Olympia according to Eusebios. The latter is taken as the true date of Pheidon's Olympic intervention. ${ }^{26}$

A further support for this construction has been found in Ephoros' statement that Pheidon had deprived the Lakedaimonians of their hegemony in Peloponnesos. ${ }^{27}$ One may suppose that for Ephoros the beginning of the Spartan hegemony was marked by the conquest of Messenia, ${ }^{28}$ completed by the king Theopompos. ${ }^{29}$ Theopompos, in turn, might have been counted by Ephoros as the 9th descendant of Temenos' brother Aristodemos, ${ }^{30}$ in which case Pheidon, the 10th from Temenos, should have come, in

${ }^{21}$ Paus. V, 3. 5.-4. 6; 8. 5ff; VI, 22. 2-4.

22 Paus. V, 9. 4.

${ }^{23}$ See n. 14, 27, 36.

${ }^{24}$ Strab. VIII, 362 = Apollodoros FGrH 244 F 334.

25 Meier (n. 19), 1747-1748; Kiechle (n. 7), 28-29.

${ }^{26}$ First by Falconer in his edition of Strabo (Oxford, 1807, I 518, commentary to VIII, 355). Followed by Weissenborn (n. 13), 19; Wade-Gery (n. 13), 761; Andrewes (n. 13), 74-77; Zörner (n. 13), 67 and others.

${ }^{27} \mathrm{FGrH} 70 \mathrm{~F} 115$.

28 According to Isokrates (Archid. 27) Spartan power in Messenia continued for about 400 years, and Diodoros (VII, 12) gave the same duration for the Spartan hegemony. This particular combination of the authors suggests that this pattern may also have been followed by Ephoros.

${ }^{29}$ Ephoros' awareness of Theopompos as the conqueror of Messenia is demonstrated by his F 216.

30 Theopompos was counted as the 9th descendant of Aristodemos by Herodotos, who, unlike the later ancients, did not count king Soos in the upper part of the Spartan Eurypontid stemma. When Soos was 
his counting, a generation after Theopompos. This would mean that Ephoros dated Pheidon in the generation after the first Messenian war. Since the war probably took place at the end of the eighth or the beginning of the seventh century BC, Pheidon's true date should fall roughly into the first half of the seventh century $\mathrm{BC},{ }^{31}$ which would fit perfectly with Apollodoros' and Eusebios' dates for the Pisatan revolt.

In this way Ol.28 (668 BC) becomes the true Olympian date for Pheidon, based on the chronicle of Hippias. ${ }^{32}$ This date is often associated in turn with the Argive victory against the Spartans in the battle of Hysiai, mentioned by Pausanias and dated to 669 BC, ${ }^{33}$ a year before the supposed date of Pheidon's Olympian intervention. In this way the battle becomes Pheidon's principal victory and possibly also the signal for the outbreak of the Messenian revolt, ${ }^{34}$ while the defeat of Pheidon and the subjection of Pisatis and Triphylia to Elis are to be considered simultaneous results of the second Messenian war. ${ }^{35}$

The dating of Pheidon to the 8th century would be, in that case, a double misconception - the result of a transcriptional error and of the incorrect interpretation of the (in itself sensible) genealogical statement of Ephoros, leading to the wrong absolute date. As a result of these errors the ancients ignored the documentarily attested date of Pheidon's agonothesia. The year continued to be considered important in Olympian history, but its true significance was misunderstood. Pheidon in his turn was separated from his true historical context and dated incorrectly to the more distant past, which would explain why he was never mentioned in connection with either the battle of Hysiai or the second Messenian war - events that must have been, in this case, of crucial importance in his career.

Such a solution is certainly ingenious and attractive and has therefore been widely accepted. But it must nonetheless be almost certainly rejected. ${ }^{36}$ Indeed, there remains the contradiction that according to Eusebios the Pisatans celebrated Ol.28 peacefully, which cannot be easily reconciled with Pheidon's violent intervention. One must also give head to the fact that a Spartan was recorded as the winner of the stadion race in O1.28 - the supposed year of Pheidon's agonothesia. ${ }^{37}$ If we assume that the Olympian chronicle has attested the date of Pheidon's intervention reliably, we must

counted, then Theopompos was the 10th from Aristodemos. The question of which version was followed by Ephoros will be discussed below (n. 81).

31 Busolt (n. 7), 613; Viedebantt (n. 13), 220; Andrewes (n. 13), 74; D. Kagan, Pheidon's Aiginetan coinage, TAPhA 91, 1960, 126.

32 Den Boer (n. 13), 59; Hammond (n. 13), 325: "the fact is that Pheidon flourished c. 670-660 BC., and we owe our knowledge of that fact to the records of the Olympic festivals."

33 Paus. II, 24, 7.

34 In this case, Pheidon could have been allied with the coalition of Messenians, Arkadians under their king Aristokratos, and Pisatans under Pantaleon that was mentioned by Apollodoros FGrH 244 F 334.

35 The date 668 BC for Pheidon's agonothesia has been almost universally associated with the battle of Hysiai: Weissenborn (n. 13), 20; Wade-Gery (n. 13), 761; Will (n. 13), 350-351; Andrewes (n. 13), 39-42; Zörner (n. 13), 66-67; Jeffery (n. 13), 136; Hammond (n. 13), 325; Figueira (n. 13 ), 16 and others. That Pheidon's victory urged the Messenians to revolt was suggested by Bradeen (n. 13), 240.

36 See Ungern (n. 13, 1869), 400-408; Meier (n. 19), 1748-1749; Huxley (n. 13), 592-593; Kelly (n. 13), 96-97; Gehrke (n. 13), 39; N. Robertson, Festivals and Legends: the Formation of Greek Cities in the Light of the Public Ritual, Toronto, Buffalo, London 1992, 210-211. The difficulties of this construction have been admitted even by its supporters (Wade-Gery (n. 13), 761).

37 According to Euseb. Chron. I, 198 Schoene the winner at Ol.28 was Charmis and according to Paus. IV, 23, 4. it was Chionis, both of them from Lakonia. 
also trust the names of the winners in this year. But a Spartan winner at the games celebrated by the Spartan arch-enemy a year after the crucial defeat of the Spartan army would certainly not be expected.

But more importantly, as will be presently demonstrated, the very basis of such a construction is unacceptable. There are all grounds for rejecting the fusion of Euphoros' account of Pheidon's defeat with that of Apollodoros of the destruction of the Pisatan towns after the last defeat of the Messenians. And certainly, one cannot change the number of Pheidon's anolympiad in Pausanias to conform to the Eusebian dates.

Ephoros certainly knew that the second Messenian war was fought two generations after Theopompos. ${ }^{38}$ Perhaps he assumed an interval of 80 years between the first and the second wars. ${ }^{39}$ That means that even if he placed Pheidon a generation after Theopompos, which in itself is rather unlikely, ${ }^{40}$ he nevertheless could not have associated him with the second Messenian war. By his reckoning the war must have broken out at least another generation later, which means that he must have considered Pheidon's downfall as something that took place before it.

Apollodoros, on the other hand, certainly dated the defeat of Pisatis and Triphylia after the second Messenian war. Furthermore, there is no reason to believe that he dated it immediately after the end of the war. Apollodoros distinguished four Messenian wars. ${ }^{41}$ We may admit that he synchronised the beginning of the Pisatan interlude at Olympia with the second war. But agonothesia reverted to the Eleians

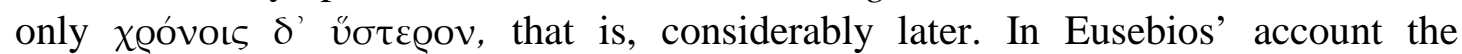
interlude ended in 576 BC, and according to Pausanias, Pisatis and Triphylia were finally subjected in the 580s, in both cases several decades after the end of the second


certainly not to be equated with the second, but with either the third or the fourth war. ${ }^{43}$ In other words, Ephoros must have believed that Pheidon was defeated before

\footnotetext{
38 Note the verses of Tyrtaios cited by him in F 216.

39 Justin. III, 5, 1, who probably followed Ephoros' account (Jacoby (n. 7), 131, n. 18; see also Busolt (n. 7), 590, n. 1). The same interval between the wars was also assumed by different chronographers (see below).

40 See n. 81.

41 Apollodoros FGrH 244 F 334. The first was the war of Theopompos, the second that of Tyrtaios, the third and the fourth were left unspecified, but the last of them was almost certainly the revolt of the Messenians in the 460s BC.

42 Pausanias dated the second Messenian war to 685-668 BC (IV, 15. 1; 23. 4), but in some cases he seems to have followed a chronology that dated the war to the 640s and 630s BC. This question as well as that of the dates of the Messenian wars in Eusebios will be considered below.

43 The dating of the end of the Pisatan agonothesia by Eusebios (572 BC) and of the destruction of Pisatan and Triphylian towns by Pausanias (after 588 BC) suggest that Apollodoros had in mind the end of his third war, which should be dated, in this case, to the end of the 7th and (or) the beginning of the 6th century BC. Indeed, the war could be connected both with Epameinondas' statement of the 230 years of Spartan power in Messenia (Plut. Mor. 194 b), which implies that Messenia was finally subdued ca. 600 BC, and with the Spartan king Leotychidas (Alkman P.Oxy. 2390; Hdt. VIII, 131. 2; Plut. Lyk. 13; Mor. 224cd) in whose time Rhianos dated the revolt of Aristomenes (FGrH 265 F 42, 43). On the other hand, the statement of Herodotos that Triphylian towns were destroyed in his time (IV, 148, 4) and the fact that according to Pausanias the spoils taken in the course of the subjection of Pisatis were used by Pheidias to make the statue of Olympian Zeus (V, 10. 2) favour the last war in the 5th century BC. The complex problem of the ancient accounts of the Messenian wars, including the so-
} 
the second Messenian war, while Apollodoros dated the subjection of Pisatis and Triphylia a considerable time after it. They almost certainly had in mind different instances, neither of which was believed to have been connected with the end of the second Messenian war. We have no grounds for fusing their accounts together.

Turning to the dates of Pausanias (Ol.8) and Eusebios (Ol.28), we must keep in mind that Pausanias probably depended on the account of Ephoros. Indeed, the last king of Argos, Meltas the son of Lakedes, was in Pausanias' account the 10th descendant of Temenos' grandson Medon. ${ }^{44}$ Meltas' father Lakedes is probably identical with Pheidon's son Leokedes, mentioned by Herodotos, ${ }^{45}$ in which case Meltas, the last Argive king according to Pausanias, must have been Pheidon's grandson. And if Pheidon's grandson was the 10th from Temenos' grandson, then Pheidon himself must have been the 10th from Temenos himself, just as we have it in Ephoros. ${ }^{46}$ Thus, Pausanias, like Ephoros, probably considered Pheidon as belonging to the 10th generation from Temenos. And this could, in the reckoning of the ancients, accord well with Ol.8 (748 BC) but certainly not with Ol.28 (668 BC). Pausanias' date is therefore logically consistent and could scarcely have resulted from any textual corruption.

The decisive factor is, however, that the dates by Pausanias, Apollodoros and Eusebios derive from different chronological systems and, therefore, simply cannot be made to agree.

Pausanias dated the first Messenian war to 743-724 BC.47 His date of Pantaleon's agonothesia - $644 \mathrm{BC}(\mathrm{Ol} .34)$ - is exactly 80 years after the end of the first war, hence distanced from the first conquest of Messenia by the two generations that were believed to have separated the two Messenian wars. ${ }^{48}$ Pantaleon was known as a leading figure of the second war. ${ }^{49}$ The date of his agonothesia in Pausanias is in turn about 4 years before the date of Tyrtaios in the lexicon of Suda, ${ }^{50}$ and the poet was believed to have come to Sparta some years after the outbreak of the second war. ${ }^{51}$ So there can scarcely be any doubt that Pausanias followed here a chronological pattern where Pantaleon's agonothesia was roughly equated with the outbreak of the second Messenian war. ${ }^{52}$ The dating of Pheidon to $748 \mathrm{BC}$ was presented by Pausanias in the

called Rhianos-hypothesis, cannot be discussed in more detail here. See E. Schwartz, Tyrtaeos, Hermes 34, 1899, 428-468; Beloch (n. 13), 262-273; Jacoby, FGrH III A 2, 1943, 109-195; J. Kroymann, Sparta und Messenien, Berlin, 1937; Kiechle (n. 7); L. Pearson, The pseudo-history of Messenia and its authors, Historia 11, 1962, 397-426; H. T. Wade-Gery, The "Rhianos hypothesis", Ancient Society and Institutions, Oxford 1966, 289-302.

44 Paus. II, 19, 2.

45 Hdt. VI, 126.

46 Beloch, (n. 13), 193; Ure (n. 13), 158; R. Drews, Basileus. The evidence for Kingship in Geometric Greece, New Haven, London 1983, 65.

47 Paus IV, 5. 10; 13, 7.

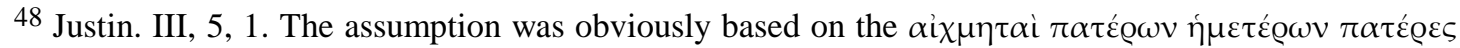
by Tyrtaios fr. 4 GP.

49 Apollodoros FGrH 244 F 334.

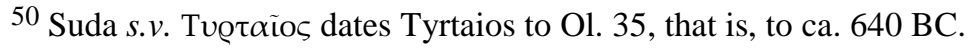

51 Paus. IV, 15, 4-7.

52 Schwartz (n. 43), 429-431; Jacoby (n. 7), 132. In the Canons of Eusebios (Chron. II, 88-89 Schoene) we find both the second war as well as Tyrtaios introduced at 36th Olympiad (636-633 BC), thus, slightly later than in the version followed by Pausanias. The difference of one Olympiad between 
same passage as that of Pantaleon to $644 \mathrm{BC}$, and should be considered as deriving from the same chronological system. Consequently, this system dated Pheidon's agonothesia 5 years (about one Olympiad) before the outbreak of the first Messenian war and 104 years (26 Olympiads) before Pantaleon's agonothesia and the outbreak of the second war. 53

According to Apollodoros the Eleians celebrated the games uninterruptedly during the first 26 Olympiads and Pisatan agonothesia began at O1.27 (672 BC). Remarkably enough, the Pisatan revolt was, according to Apollodoros, separated from the first recorded Olympic games by exactly the same interval (26 Olympiads $=104$ years) that in Pausanias' account separated Pantaleon's agonothesia from that of Pheidon. ${ }^{54}$ In other words, the beginning of the period of the 26 Olympiads of the Eleian presidency before the 7th century Pisatan interruption was equated by Apollodoros with the establishment of the games $(776 \mathrm{BC})$ and by Pausanias with Pheidon's agonothesia (748 $\mathrm{BC})$. We know that according to Pausanias the first Messenian war broke out in $743 \mathrm{BC}$ - about one Olympiad after Pheidon. And remarkably enough, in Orosius we find the outbreak of the war dated to $773 \mathrm{BC}^{55}$ - about one Olympiad after Ol.1. ${ }^{56}$ In other words, the outbreak of the first Messenian war was also related to both dates. Thus, there are sufficient grounds for supposing that we have here two systems where Ol.1 at 776 and $\mathrm{Ol} .8$ at 748 mark rather similar turns of events. Both Olympiads marked a decisive stage in Olympian history, ${ }^{57}$ were supposed to have been followed almost immediately by the outbreak of the first Messenian war, and were separated by 26 Olympiads from the beginning of the Pisatan agonothesia.

But there seems to have been one more chronology. As stated above, Eusebios dated the Pisatan revolt to $660 \mathrm{BC}$. The first Messenian war was probably dated by him to the years from 757 to 738 BC. ${ }^{58}$ Its end thus comes roughly 80 years before the Pisatan revolt. We have seen that in the chronology followed by Pausanias the Pisatan interlude was roughly equated with the outbreak of the second Messenian war and separated from the end of the first war by 80 years. And when we find in Eusebios the beginning of the Pisatan interlude separated from another date of the end of the first Messenian war by almost exactly the same interval, then it is very likely that in this

the chronologies of Pausanias and Eusebios is, however, quite usual and does not call for any special comment here (see n. 74).

53 See Schwartz (n. 43), 429-431; Jacoby (n. 7), 132; FGrH III b 1, 1955, 641; Mosshammer (n. 14), 204-209. Probably it was the chronology of the Lakonian Sosibios (see below).

54 This fact has been noted by J. Mähly, Die Tyrann Pheidon von Argos, RM 9, 1854, 615-616 and O. Viedebantt, Forschungen zur altpeloponnesische Geschichte. 2. Elis und Pisa, Philologus 85, 1930, 2931.

55 Orosius (I, 21, 3) dated the outbreak of the war 20 years before the foundation of Rome in $753 \mathrm{BC}$.

56 I can see no reason to associate this date with the beginning of the 400 years of Spartan hegemony mentioned in Isokrates, Archid. 27 and Diodoros VII, 12 (as have done Jacoby (n. 7), 130, n. 9 and Kiechle (n. 7), 22). Indeed, the hegemony was achieved with the end, not the beginning, of the war.

57 We must recall that Isidorus (n. 12) dated Pheidon to Ol.1 and note also that according to Eusebios (Chron. I, 227 Schoene) the Macedonian dynasty was founded by Karanos 453 years before the death of Alexander the Great, thus, in 776 BC $(323+453=776$; see Schwartz (n. 14), 75-77). Since Karanos was known as Pheidon's brother (Synkellos 373, 498), this also implies 776 BC for Pheidon's date (see below).

58 See Jacoby (n. 7), 128-130. 
case the beginning of the interlude was also synchronised with the outbreak of the second Messenian war. ${ }^{59}$

Thus, there are signs of three parallel chronologies. They seem to have dated the beginning of the first Messenian war to the years 773, 757 and $743 \mathrm{BC}$, at least two of them placing it about one Olympiad after an occurrence in Olympia (either Ol.1 or Pheidon's agonothesia), while the outbreak of the second war together with the Pisatan revolt against the Eleians was dated almost exactly 100 years later (672, 660 and $644 \mathrm{BC}$ ).

But in addition, there are several indications that certain events in Corinthian history were also dated according to these three chronologies. First, according to Diodoros, the Corinthian kingship was abolished in $747 \mathrm{BC},{ }^{60}$ that is, a year after Pausanias' date for Pheidon. But the Canon of Eusebios dated the single year of the last Corinthian king to $777 \mathrm{BC}-$ a year before the first Olympic games. ${ }^{61}$ In other words, the end of the Corinthian kingship seems to have been attached to both dates. Next, the Corinthian poet Eumelos was dated by Eusebios to 744 BC. ${ }^{62}$ Roughly the same date $(\mathrm{Ol} .9=744-741 \mathrm{BC})$ was given by Suda for the cyclic poet Arktinos. ${ }^{63}$ The date falls one Olympiad after Pheidon and in the first year of the first Messenian war, according to Pausanias. But both poets were also dated to 762 or $761 \mathrm{BC},{ }^{64}$ a few years before $757 \mathrm{BC}$, another date for the outbreak of the first Messenian war. And for Arktinos there was also the date $775 \mathrm{BC}, 65$ a year after the first Olympic games and a few years before Orosius' date for the beginning of the Messenian war (773 BC). Thus, all the dates of Eumelos and Arktinos correspond roughly to the dates for the outbreak of the first Messenian war. ${ }^{66}$ But Eumelos was, according to Clemens, a contemporary of Archias, the founder of Syracuse, ${ }^{67}$ and hence synchronised with the beginning of Corinthian western colonisation. So we can assume that the foundation of Syracuse was also a part of this synchronisation. And in fact, we find that Marmor Parium dated the foundation of Syracuse by Archias to the 21st year of the Athenian archon Aischylos, ${ }^{68}$ which falls, according to the chronology of Kastor, in 758 BC. 69 The same date for the foundation of Syracuse is implied by the book of Diodoros, which reveals a chronology of the western colonies with dates 23 years earlier than

\footnotetext{
59 On the whole argument see Schwartz (n. 43), 431-433; Jacoby (n. 7), 129-132; FGrH III b 1, 1955, 641; Mosshammer (n. 14), 204-209.

6090 years before the rise of Kypselos (657 BC), according to Diodoros VII, 9.

61 Abr. 1239. in the Armenian version. It was dated a year earlier by Jerome (Abr. $1238=778 \mathrm{BC})-$ Euseb. Chron. II, 76 Shcoene.

62 Ol. 9. 1; Abr. 1272. Euseb. Chron. II, 80, 83 Schoene.

63 Suda, s.v. A@ктіvos.

64 Ol. 4. 3; Abr 1255. Euseb. Chron. II, 80-81 Schoene. The Lakonian poet Kinaithon was dated by Jerome to the same year (Ol. 4. 2), which suggests that he was also attached to this synchronisation.

65 Ol. 1. 2; Abr. 1241. Euseb. Chron. II, 78-79 Schoene.

66 Mosshammer (n. 14), 198-203 suggests that the akme of Arktinos was attached to Ol.1, that of Eumelos to the outbreak of the Messenian war and when synchronised, they were dated somewhere close to the mid-point between these individual dates (which was also a possible date for the foundation of Syracuse - see below). In this case we must see in the mention of Suda (the date of Arktinos at O1.9) a rather careless mistake. This is, however, not necessary if we assume that the dates derive from different chronologies.

67 Clemens, Strom. I, 131.

68 Marm. Par. FGrH 239, 31.

${ }^{69}$ Kastor FGrH 250 F 4. See Mosshammer (n. 14), 202.
} 
those of Thukydides. ${ }^{70}$ Thukydides dated the foundation of Syracuse to 734 BC, so that in the other version it should have been dated to $757 \mathrm{BC}(734+23=757)$. Thus, 758 or 757 BC was a possible date for the foundation of Syracuse. And, as we have seen, Eumelos and Arktinos were placed a little earlier (761 or 760 BC). All this demonstrates that the outbreak of the Messenian war has been synchronised with the beginning of the western colonisation and the date of Eumelos and Arktinos attached to this synchronisation.

So we have the following synchronisations: (1) around the year $776 \mathrm{BC}$ the first Olympic games, the end of the Corinthian kingship, Arktinos, and some years later the outbreak of the Messenian war;11 (2) in the year 762 or 761 BC Arktinos and Eumelos, a little later (758 or $757 \mathrm{BC}$ ) the outbreak of the Messenian war and the start of Corinthian western colonisation; (3) in the year 748 BC Pheidon and (a year later) the end of the Corinthian kingship, and after a few years (743 BC) the outbreak of the Messenian war, Arktinos and Eumelos, hence also the beginning of the western colonisation. And in every case we find the dating of the outbreak of the second Messenian war and/or of the Pisatan revolt against the Eleians 25 Olympiads (about 100 years) after the outbreak of the first war and (or) 26 Olympiads (104 years) after the previous incident at Olympia.

This cannot be a coincidence, it demonstrates the basic synchronisations on which the ancient chronology of early Peloponnesian history was built. An occurrence at Olympia (either the establishment of the games or Pheidon's agonothesia) was synchronised with the end of the Corinthian kingship; these events were supposed to have been followed almost immediately by Corinthian western colonisation and the outbreak of the first Messenian war, to which time was dated also the akme of Arktinos and Eumelos. The Pisatan revolt against the Eleians and the outbreak of the second Messenian war were dated almost exactly 100 years after the outbreak of the first war. These synchronisations were dated according to at least three different absolute chronologies. The final defeat and the expulsion of the Pisatans were related to these sequences rather loosely and were supposed to have followed during the first decades of the sixth century BC.

Thus, we have (1) the high chronology:

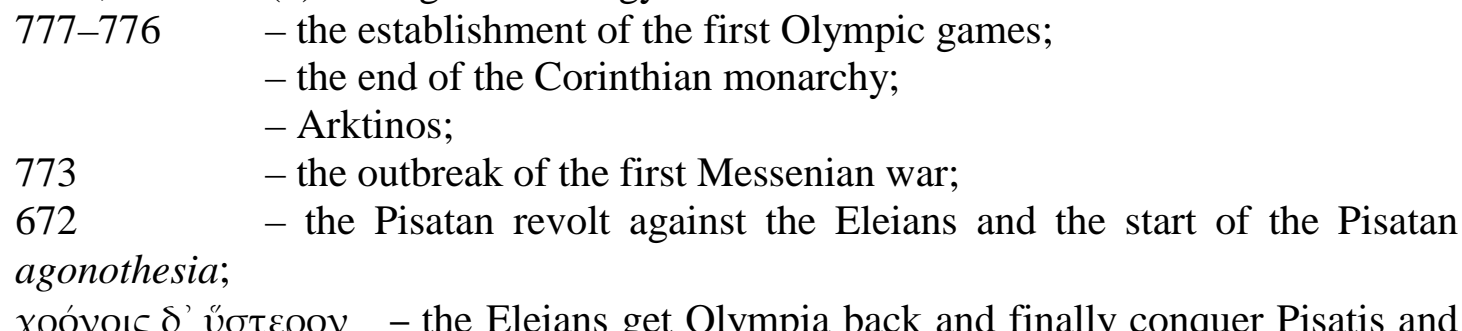
Triphylia;

\footnotetext{
${ }^{70}$ According to Diodoros XIII, 59 Selinus was founded 242 years before its destruction in 409, that is in $651 \mathrm{BC}$, which is 23 years earlier than according to Thukydides, who dated its foundation to $628 \mathrm{BC}$. Diodoros' date of Selinus' foundation was followed in turn by Eusebios - by Jerome we find it dated to the year 647 (Chron. II, 89 Schoene). T. J. Dunbabin, The Western Greeks, Oxford 1948, 437 has tried to explain this date as a simple mistake, but see Busolt (n. 7), 385, n. 2.

${ }^{71}$ Perhaps we should add here Pheidon, according to Isidorus (see n. 57).
} 
(2) the middle chronology:
762 or 761 - Arktinos and Eumelos;
758 or 757 - the outbreak of the first Messenian war;
- the foundation of Syracuse;
668
660
- the Pisatans celebrate the games in the absence of the Eleians;
572
- the Pisatan revolt and the start of the Pisatan agonothesia;
- the Eleians get Olympia back under their sway;

(3) the low chronology:

$\begin{array}{ll}\text { 748-747 } & \text { - Pheidon's agonothesia; } \\ & - \text { the end of the Corinthian monarchy; } \\ \text { ca. } 743 & \text { - the outbreak of the first Messenian war; } \\ & - \text { Arktinos and Eumelos; } \\ & \text { - the foundation of Syracuse (?); } \\ & - \text { the Pisatan revolt and Pantaleon's agonothesia; } \\ & - \text { the outbreak of the second Messenian war; } \\ & - \text { Tyrtaios; } \\ 540 & - \text { the Pisatans plot against Elis under Damophon; } \\ 588 & - \text { the destruction of Pisatan and Triphylian towns; } \\ \text { thereafter } & - \text { Olympia back under Eleian control. }{ }^{72}\end{array}$

Such a conclusion has obvious consequences for the problem of the dating of Pheidon. It makes it clear that the date of his violent agonothesia (748 BC) was intentionally placed slightly before the outbreak of the first Messenian war. The dating of the Pisatan agonothesia to $668 \mathrm{BC}$ derives from another chronology, where it was placed before the outbreak of the second war and the simultaneous revolt of the Pisatans. These dates were certainly intended to mark different events at different times and there is no warrant for making them conform by means of a simple emendation.

At the same time, the existence of the parallel chronologies demonstrates that there was no universally accepted chronology of the events of early Olympian history.

\footnotetext{
72 It seems that these parallel chronologies were not confined to the events of the eighth and seventh centuries BC, but extended upwards to the different dates of the Herakleid invasion. Indeed, there is the same discrepancy of about 30 years between the date of the Herakleid invasion in Ephoros (1069 BC) and in Apollodoros (1104 BC - FGrH 244 F 61) as can be observed between our high and low chronologies. It is noteworthy that the lists of the Spartan kings in Diodoros (VII, 8), attached at their lower end to the first Messenian war, dated, according to our middle chronology, to 757-738 BC (indeed, Jacoby (n. 7), 129-130 calculated these dates according to the lists of Diodoros - see below, especially n. 77) and stated as beginning in 1104 BC (the Apollodorean date of the Herakleids) in fact are too short and hence begin only in 1069 BC (the Ephorean date of the Herakleids). Diodoros' list of the Corinthian kings (VII, 9) that ends in 747 BC (the crucial point in our middle chronology) and also was stated as beginning in $1104 \mathrm{BC}$ (the Apollodorean date) in fact begins 30 years later, in $1074 \mathrm{BC}$ (not very different from the Ephorean date). In the Canon of Eusebios (Chron. II, 54-79 Schoene) the lower ends of the Spartan Agiad stemma and the list of the Corinthian kings (the Eurypontid stemma is missing in the Canon) are synchronised with the date of the first Olympiad (the crucial point of the high chronology) while their beginning is dated to $1102 \mathrm{BC}$, very close to the Apollodorean Herakleid date. In other words, the upper ends of the stemmas are attached either to the Apollodorean or to the Ephorean date of the Herakleid invasion, and their lower ends conform to our three chronologies. Obviously, all three chronologies were, in different ways, attached either to the Ephorean or Apollodorean Herakleid dates. For a detailed discussion of the problem of the inconsistencies in these stemmas with their different explanations see Schwartz (n. 14), 60-65, 73-74; Jacoby (n. 7), 76-97; W. G. Forrest, Two chronological notes, CQ 19, 1969, 106-110; Mosshammer (n. 14), 184-186.
} 
Otherwise how could it be that the Pisatan revolt (or revolts) were dated differently in the different chronological systems? Nor could there have been such uncertainty about the dates of the second Messenian war, obviously attached in some way to Olympian history, if the dates of the Olympian events had been known and universally accepted. All this should make us rather sceptical about the documentary basis of the chronology of early Olympian history and thus about the possibility of establishing the exact date of Pheidon's agonothesia. ${ }^{73}$ We must admit that, most probably, the dates of the anolympiads simply were not fixed in the chronicle of Hippias and the date of Pheidon's agonothesia was therefore unknown to the ancients. The statement that it was left unrecorded by the Eleians was probably a convenient explanation of the fact. What the ancients knew (or believed that they knew) was the sequence of events, but apparently nothing certain about the exact absolute dates. Consequently, the sequences were dated differently by different chronographers. And it would be nonsense to try to put things in order by changing the dates in one system to match those of some other events in another. ${ }^{74}$

Therefore, we must admit that all the ancient dates for Pheidon were the results of some kind of chronological constructions based on certain synchronisations. More particularly, the date $748 \mathrm{BC}$ in Pausanias was in all probability intentionally synchronised with the end of the Corinthian kingship and calculated to fall a few years before the subsequent western colonisation and the outbreak of the first Messenian war, dated to 743-724 BC (or, vice versa, the start of the first Messenian war was calculated to fall a few years after Pheidon's agonothesia).

When trying to identify the author of the chronology that provides this date, ${ }^{75}$ we are led to the Lakonian Sosibios. Indeed, the dates 743-724 BC for the first Messenian

73 A. R. Burn, Dates in Early Greek History, JHS 55, 1935, 144. This is not necessarily to contest the reliability of the list of olympionikai. But we must admit that the list probably did not contain anything of significance about political history (on the nature of the eponymous lists see F. Jacoby, Atthis: The Local Chronicles of Ancient Athens, Oxford 1949, 169-188 with notes).

74 If one still wants to connect Pheidon with Pantaleon and the second Messenian war, and to discover in this way his exact Olympian date, there seems to be no reason to prefer the dates of the Pisatan interlude in Eusebios to those in Pausanias (Pausanias' dates have been preferred by Mähly (n. 54), 614-616; Videbannt (n. 13), 228-224; see also the somewhat different combination by A. Hönle, Olympia und die Politik der griechischen Staatenwelt, Bebenhausen 1972, 36-37). The date of the battle of Hysiai would be of no help, since this too must derive from one or another chronological system and, therefore, has no independent value. I can see no possibility of determining to what system and in which way it was related. It has sometimes been assumed that this battle marked the beginning of the second Messenian war. But Pausanias put it a year before his date for the end of the war (dated 668 BC by Paus. IV, 23. 4). The matter is further complicated by the fact that several Olympiads were dated by Pausanias four years later than by Eusebios (see Beloch (n. 13), 156-159; F. Jacoby, Die attische Königsliste, Klio 2, 1902, 410, n. 2; J. Hejnic, Pausanias the Perieget and the Archaic History of Arcadia, Prague 1961, 111-118). So if the battle was chronologically connected with the first Olympic victory of Chionis (according to Pausanias the battle was fought a year before it - compare II, 24. 7. and IV, 23. 4), it could be dated to $665 \mathrm{BC}$, a year before Chionis' first victory, according to Eusebios (I, 198). In any case, there is no reason to regard Pausanias' date of the battle as a kind of keystone for 7th century Peloponnesian chronology (see also Busolt (n. 7), 596-597). This is not to contest the reality of the battle itself (as do D. Kelly, Argives defeat the Spartans at Hysiae in 668 BC? AJPh 91, 1970, 31-42; Robertson (n. 36), 208-216; M. Meier, Aristokraten und Damoden, Stuttgart 1998, 73).

75 I will not speculate on the origins of the two higher chronologies. It can only be said that the high chronology seems to accord with the Apollodorean dates - at the upper end it was attached to the date $1104 \mathrm{BC}$ for the Herakleid invasion (see n. 72) and at the lower end to the Apollodorean date $672 \mathrm{BC}$ for the beginning of the Pisatan agonothesia. Jacoby (n. 7), 75-97, 129-132 has considered the two 
war in Pausanias accord with the Sosibian dates for the Spartan Eurypontid kings. Sosibios dated the reign of Theopompos from $770 \mathrm{BC}$ onwards, ${ }^{76}$ so that Pausanias' dates for the outbreak and the end of the war fall in the 28th and 47th years of his reign. In our middle chronology the beginning and the end of the war were dated roughly to the same years of Theopompos' reign. ${ }^{77}$ There are therefore grounds for believing that the first Messenian war used to be dated from the 28th to the 47th years of Theopompos' reign, and that Pausanias, whose dates for the war agree in that case with the Sosibian dates for Theopompos, has here followed the Sosibian chronology. ${ }^{78}$

But the chronology of Sosibios was in turn very close to Ephoros' genealogical reckoning. As far as can be observed, the Sosibian dates of the Spartan kings accord quite well with the datings of the respective generations by Ephoros. According to Sosibios, Charillos ruled from 873 to $810 \mathrm{BC}$, Nikandros from 809 to $771 \mathrm{BC}$, and Theopompos from $770 \mathrm{BC}$ onwards. ${ }^{79}$ Ephoros should have dated the two generations of the reign of Charillos ${ }^{80}$ to ca. 870-803 BC, that of Nikandros to ca. 803-770 BC and Theopompos from ca. $770 \mathrm{BC}$ onwards. ${ }^{81}$ The correspondence is almost perfect and suggests that this part of the Sosibian chronology was basically built on the genealogical framework of Ephoros. ${ }^{82}$

Ephoros certainly touched upon Pheidon's connections with Eleian-Olympian and Spartan history. In Spartan history, the 10th generation from the Herakleid invasion

higher chronologies as a single one and identified it as Apollodorean, but has been forced to admit an additional king (Menelaos) into the Agiad stemma and to add 29 years to the last Corinthian king Automenes. His point of view has since been generally accepted; but see Forrest (n. 72), 108-110.

76 FGrH 595 F 2 with Jacoby's commentary; see also below.

77 According to Diodoros (VII; 8), Theopompos reigned for 47 years and his 10th year fell in Ol.1 (776 $\mathrm{BC})$, which means that he must have reigned 785-738 BC. Thus, the outbreak of the war (757 $\mathrm{BC})$ came in his 29th year and its end (738 BC) immediately after his last, 47th, year (see Jacoby (n. 7), 128-130; Mosshammer (n. 14), 205-206).

78 For the whole argument see Schwartz (n. 43), 429-431; Jacoby (n. 7), 128-132; FGrH III b 1, 1955, 641; Mosshammer (n. 14), 204-209. Such constructions are inevitably uncertain, but I can see no reason to contest this one (as does V. Parker, The dates of the Messenian war, Chiron 21, 1991, 26-27).

${ }^{79}$ Sosibios FGrH 595 F 2.

${ }^{80}$ Charillos was supposed to have acceded to the kingship right from birth (FGrH 70 F 149; Plut. Lyk. 3 ) and must therefore have reigned for two generations - that of his father and his own.

81 This must have been the chronology of Ephoros if he counted the king Soos between Prokles and Eurypon in the upper part of the Eurypontid stemma. This has sometimes been questioned (Forrest ( $\mathrm{n}$. 72), 109). Indeed, Soos was absent in Herodotos VII, 204, but was counted by the later authors. It is true that Ephoros called Prokles the son of Eurypon (F 117) which leaves no place for Soos between them. But the fact that he considered Lykourgos the 6th descendant of Prokles (F 149) and the 11th descendant of Herakles ( $F$ 173) demonstrates that his chronological framework was built on the stemma in which Soos was present. This is evident also from his picture of the first Messenian war. It was provoked by the murder of the Agiad king Teleklos (F 216), the 9th descendant of Aristodemos and the father of Alkamenes. Thus, the war could not have broken out before the 10th generation, that of Alkamenes. Since Ephoros certainly knew that Theopompos was the conqueror of Messenia (F 216), he could not have placed him before the 10th generation, which was only possible if Soos was counted. (The counting of Soos by Ephoros has been presupposed by Busolt (n. 7), 613, n. 1; Jacoby (n. 7), 115; D. W. Prakken, Studies in Greek Genealogical Chronology, Lancaster 1943, 92. Kiechle, (n. 7), 21-22 and Lakonien und Sparta, München 1963, 169-172, has tried to resolve the problem by suggesting that Soos was inserted during the time when Ephoros was writing, so that he was absent at the beginning, but present in the later parts of his work.) See also n. 84 .

82 We could even suggest that the Sosibian chronology was essentially the chronological framework of Ephoros provided with exact dates (thus, rather cautiously, Jacoby, FGrH III b 2, 1955, 370, n. 36). 
was most probably that of the kings Alkamenes and Theopompos ${ }^{83}$ and of the outbreak of the first Messenian war. ${ }^{84}$ In the context of Olympian history this generation came immediately after the establishment of the games by Iphitos. These synchronisations could have been intentional. ${ }^{85}$ Ephoros' account of Pheidon clearly pointed out some connection with Iphitos - Pheidon violated what had previously been established by Iphitos ${ }^{86}$ - and the number of the generation could have been mentioned to establish the temporal relationship of these figures. ${ }^{87}$ Equally, there might have been something in Pheidon's relations with the Spartans that led Ephoros to connect him with either of the Spartan kings, though we have no particular evidence to support this point.

But Pheidon was also connected with Corinthian history. According to Nikolaos of Damascus he was killed in the conflicts at Corinth while trying to help one of the fighting factions. ${ }^{88}$ Since Nikolaos generally reflected the Ephorean account of early Peloponnesian history, ${ }^{89}$ it is quite safe to assume that this was so in the present case as well. Thus, Ephoros probably let Pheidon perish in some strife in Corinth. And an appropriate context is provided by Diodoros, again an author who usually relied on Ephoros. The last Corinthian king, Telestes, who was violently overthrown by his relatives, was in Diodoros' account the 9th descendant of the Corinthian Herakleid oikistes Aletes. ${ }^{90}$ There are grounds for suggesting that according to Ephoros, Aletes had conquered Corinth a generation after the main Herakleid invasion. ${ }^{91}$ And since

83 Alkamenes was certainly considered to be the 10th descendant of Temenos' brother Aristodemos. The same holds true for Theopompos if we accept that Ephoros had counted Soos in the upper part of the Eurypontid stemma.

84 Ephoros probably believed that the war broke out close to the end of the 10th generation. The insertion of Soos in the upper part of the Eurypontid stemma was probably due to the need to make the reign of Theopompos at least partially overlap with that of Polydoros, who was later considered to be Theopompos' colleague in the Messenian war (if Soos was not counted, then Theopompos came two generations earlier than Polydoros, so that their contemporaneity would have been quite impossible). Thus, if Ephoros counted Soos, he must also have known about Theopompos' and Polydoros' contemporaneity (this might have been apparent from the poetry of Tyrtaios - see Kiechle (n. 81), 169173; W. G. Forrest, The date of the Lykourgan reforms in Sparta, Phoenix 21, 1967, 158-166). But even with Soos, Theopompos still remained a generation earlier than Polydoros. Therefore, Ephoros must have assumed a rather long reign for Theopompos, in order to make his contemporaneity with Polydoros possible, and he must have believed that the Messenian conquest took place at the end of his reign. Events were certainly imagined in this way by the later chronographers. See Jacoby, FGrH III b 1, 1955, 641; Mosshammer (n. 14), 205-206.

85 When Ephoros noted that Pheidon was the 10th from Temenos, this was almost certainly not mentioned only for the sake of genealogical interest (as suggested by Andrewes (n. 13, 1949), 74), but was intended to establish Pheidon's approximate date. The few genealogical statements we have in Ephoros' early Peloponnesian history all have a chronological bearing - note F 149 (the temporal relationship of Lykourgos and Althaimenes), F 173 (Lykourgos) and F 137 (Sicilian colonies).

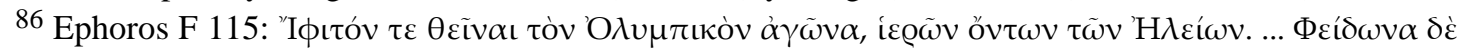

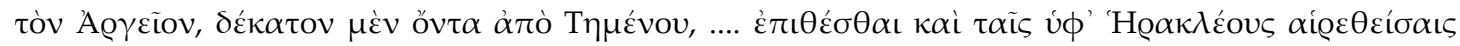

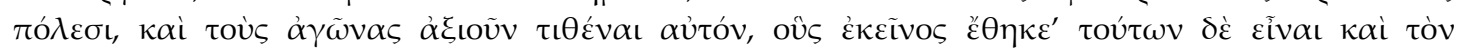

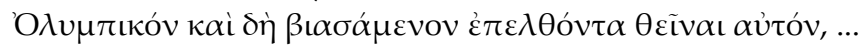

87 That the date of the first Olympic games was of any significance in Ephoros' reckoning is demonstrated by the fact that he dated Homer 100 years before them (F 102). See R. Laqueur, Zur griechischen Sagenchronographie, Hermes 42, 1907, 527.

88 FGrH 90 F 35.

${ }^{89}$ R. Laqueur, Nikolaos, RE XVII 1, 1936, 375; Jacoby, FGrH II C, 1926, 242-243.

90 Diod. VII, 9.

91 Ephoros' account of the Herakleid invasion and its consequences can be tentatively reconstructed by F 18, 115, 116, 117 and 118, combined with Nic. Dam. 90 F 28, 30, 31, 34; Konon 26, 36, 47; Diod. 
according to Diodoros the Herakleids gave Corinth to Aletes when they had already conquered the rest of Peloponnesos (except Arcadia), it is almost certain that he followed the same version. Thus, Diodoros must have presented Ephoros' account of early Corinthian history. Now, since, in this account, Aletes was active a generation after Temenos, it is obvious that Telestes, the 9th from Aletes, should have belonged to the 10th generation from Temenos, that is, to the generation of Pheidon. The end of this generation should have been marked by the death of both Telestes and Pheidon. ${ }^{92}$ Thus, there are sufficient grounds for believing that, according to Ephoros, Pheidon perished in the same strife that led to the abolishment of the Corinthian kingship and the establishment of the Bakchiad oligarchy.

So we can see that the basis for the synchronisations of the later chronographers was provided by Ephoros who had synchronised Pheidon with the end of the Corinthian kingship as well as with the Spartan kings of the time of the first Messenian war and dated him to the first generation after the establishment of the Olympic games. His account must have had a great influence on the later authors in their attempts to establish the precise dates of the events of early Peloponnesian history.

But in addition, Pheidon was involved in the story about the violent death of a Corinthian boy, Aktaion, and the foundation of Syracuse. It was said that Pheidon had attempted an unsuccessful plot against Corinth which had caused one of his followers, either Abron or Melissos, to emigrate to the Isthmian city where his grandson or son Aktaion was murdered by a mighty Corinthian, Archias. The crime was said to have invoked divine vengeance and led to the expulsion of the Bakchiads and the foundation of Syracuse by Archias and Korkyra by Chersikrates. ${ }^{93}$ We do not know if Ephoros told the story of Aktaion and if so, whether Pheidon was involved in his account. ${ }^{94}$ But in any case, it must have given the chronographers sufficient grounds

VII, 13. 1 and Strabo IX, 393; XIV, 653. All these agree perfectly and present a picture in which Hippotes, Aletes' father and the companion of Temenos and his brothers, was expelled because of the murder of the seer Karnos, and Aletes could have founded the Dorian Corinth only in the next generation. Thereafter he led the campaign of the Dorians against Athens (Konon 26), which was followed by the emigration of Temenos' grandson Althaimenes at the beginning of the third generation (Konon 47; Strabo XIV, 653). This version was also followed by Apollodoros, Bibl. II, 8, Paus. III, 13, 4 , and accords with the story of how Aletes obtained the Corinthian land according to the prediction of Zeus' oracle at Dodona (Schol. Pind. Nem. VII, 155; Diogenian. IV, 27; Zenob. III, 22). There was certainly another version of the tradition as well, which synchronised Aletes with the main Herakleid invasion (Satyros P.Oxy. 2465, fr. 3. II, 12-20; Scol. Pind. Pyth. V, 106; Schol. Callim. h. II, 51; also the genealogy regarding Aletes as Herakles' 5th descendant: Paus. II, 4. 3; Schol. Pind. Ol. XIII, 17) and Jacoby (n. 7), 94 has ascribed it to Ephoros. But his main argument that since in Ephoros' F 18 Aletes is listed among the Herakleid oikistai he must have been considered a contemporary of Temenos, Aristodemos and Kresphontes, meaning that Ephoros must have followed the latter version, is not valid, because the list of oikistai definitely contains certain figures - Kissos, Phalkes, Deiphontes - of the second generation. On the ancient tradition about the foundation of Dorian Corinth see Will (n. 13), 284-288; G. L. Huxley, The Malian boat (Aristotle F 554), Philologus 119, 1975, 140-142; N. Robertson, The Dorian migration and Corinthian ritual, $\mathrm{CPh} 75,1980$, 4-10; J. Salmon, Wealthy Corinth, Oxford 1983, 38-39.

92 Ephoros has been considered as the source of the story of Telestes by Drews (n. 46), 53.

93 Plut. Mor. 772-773; Scol. Ap. Rhod. IV, 1212. The story was also mentioned, without reference to Pheidon, by Diod. VIII, 10; Max. Tyr. 24, 1; Parthen. Erot. 14. There is no reason to discuss here whether the connection of Pheidon with the colonisation in this story was correct or not. The point is that the ancients accepted this connection.

94 Ephoros certainly gave a rather substantial account of the western colonisation $(F$ 137, 138) and must have related something about the foundation of Syracuse by Archias (Diodoros VIII, 10. and 
for regarding Pheidon and Archias as contemporaries and to synchronise Pheidon's end with the foundation of Syracuse. ${ }^{95}$

Now, a link between these events and the Messenian wars was provided by the Corinthian epic poet Eumelos. On the one hand, the ancients considered him a contemporary of Archias. ${ }^{96}$ On the other hand, he was known to have composed a hymn to Delian Apollo for the Messenians at the time of king Phintas, who was believed to have reigned in the last generation before the war. ${ }^{97}$ The synchronisation of Eumelos, Archias and the outbreak of the Messenian war was therefore quite reasonable. ${ }^{98}$ But Archias and the beginning of the colonisation were, according to the story of Aktaion, synchronised with Pheidon and he, according to Ephoros, in turn with Telestes and the end of the Corinthian kingship. All this made the synchronisation of Pheidon, Telestes, Archias, Eumelos and the outbreak of the Messenian war perfectly reasonable. As a result, Pheidon and the end of the Corinthian monarchy were dated immediately before the outbreak of the first Messenian war.

\section{The statements of Theopompos, Marmor Parium, Eusebios and Isidorus}

According to Theopompos, Pheidon was the 6th descendant of Temenos. ${ }^{99}$ According to Marmor Parium he was the 11th from Herakles, hence the 7th from Temenos, 100

Strabo IV, 268. could well represent Ephoros' account). Marmor Parium, the chronicle that has been supposed to have used Ephoros as its principal source (Jacoby, FGrH II D, 1930, 683-684), dated Archias to the 10th generation from Temenos, thus, to the same generation where Ephoros placed Pheidon. (Jacoby's conjecture in FGrH II D, 1930, 683-684 that the datings of Pheidon and Archias in Marmor Parium should be exchanged so that the Argive ruler would become the 10th from Temenos and the Syracusan oikistes the 11th from Herakles, must be rejected on two principal grounds. First, the dating of Archias to the 21st year of Aischylos in Marmor Parium (according to the chronology of Kastor the 21st year of Aischylos is dated as $758 \mathrm{BC}$, a possible date for the foundation of Syracuse see above) makes sense if Archias was supposed to have been the 10th from Temenos, not the 11th from Herakles. And second, Pheidon as the 11th from Herakles (that is, the 7th from Temenos) accords perfectly with what was assumed about his genealogical position in connection with the pedigree of Macedonian kings (see below) and cannot therefore be taken as a result of any corruption (see also R. v. Compernolle, Syracuse, colonie d'Argos? Kokalos 12, 1966, 77-79). All this could well suggest that the story was presented by Ephoros and Pheidon had a place in it. But at the same time, the geographical poem of Pseudo-Skymnos, again a source that may have followed Ephoros (F $137 \mathrm{~b}$ ), stated explicitly that this colonisation began in the 10th generation after the Trojan war, which is to be equated with the 7 th generation from Temenos. Had this been the point of view of Ephoros, he obviously could not have connected Archias and the beginning of the colonisation with Pheidon.

95 Note Marm. Par. 30 where Archias was considered the 10th descendant of Temenos. The connection of Archias and Pheidon was apparently different in different accounts. According to Plutarch (Mor. 772-773) Pheidon was active a generation before Archias. The scholiast of Apollonios, on the other hand, considered Pheidon, Archias and Aktaion's father Melisson as roughly contemporaries.

96 Clemens (n. 67).

97 Paus. IV, 4. 1; 33. 2.

98 See C. M. Bowra, Two lines of Eumelus, CQ 13, 1963, 145-153; Mosshammer (n. 14), 201-203.

99 Diod. VII, 17 = FGrH 115 F 393, which gives the following pedigree: Temenos, Kissos, Thestios, Merops, Aristodamidas, Pheidon, Karanos.

100 Pheidon as the 7th from Temenos is also implied by the stemmas in which Karanos, the founder of the Macedonian dynasty and Pheidon's son or brother according to the tradition (see n. 107), was listed as Temenos' 7th descendant without mention of Pheidon among his ancestors (Satyros FHG III, 164165, fr. 21; Synkellos 499). On the character and origin of these lists see Beloch (n. 13), 192-193; Jacoby FGrH II C, 1926, 400-402; Drews (n. 46), 67-70. 
and was dated to the year 895 BC. ${ }^{101}$ Both the 7 th and the 6th generations from Temenos offered plausible dates for the Spartan lawgiver Lykourgos. Indeed, Lykourgos was the 7th from Aristodemos (Temenos' brother) according to the canonical genealogy if Soos was counted ${ }^{102}$ and the 6th either without counting Soos, or if one followed the version of the Lykourgan genealogy given by Simonides. 103 One must also note that the date 895 BC, proposed by Marmor Parium for Pheidon, was 299 (roughly 300) years after Timaios' date for the fall of Troy (1194 BC). ${ }^{104}$ And there is exactly the same interval between the fall of Troy and Lykourgos in the chronologies of Eratosthenes and Apollodoros, where these instances were dated to 1183 and 884 BC respectively. ${ }^{105}$ Thus, Pheidon and Lykourgos were placed in the same generation and, accordingly, were distanced from the Trojan war by the same gap of 299 years. ${ }^{106}$ This clearly suggests that Lykourgos and Pheidon were synchronised with each other.

In fact, this synchronisation can be demonstrated in other ways as well. Velleius Paterculus explicitly synchronised three epochal events of world history: (1) the destruction of Assyria by the Medes and the beginning of the Median hegemony in Asia, (2) the foundation of the Argead dynasty in Macedonia by Karanos, the son or the brother of Pheidon according to the ancients, ${ }^{107}$ and (3) Lykourgan legislation in Sparta. ${ }^{108}$ This set of synchronisations has left clear traces in different chronological systems. Velleius himself dated all these events to the year $818 \mathrm{BC}$. This date can also be found in the Chronicle of Eusebios where the defeat of the last Assyrian king Sardanapallos and the first year of the Median Arbakes as well as Lykourgan legislation were dated to Abr. 1198 (819 BC). ${ }^{109}$ But in Eusebios we also find that the beginning of Karanos' reign in Macedonia was dated to the year of the first Olympic games in 776 BC. And according to Isidorus this was the date of Pheidon and of the death of Sardanapallos and the transfer of the hegemony from the Assyrians to the Medes. ${ }^{110}$ Indeed, it was a possible date for Lykourgos as well. ${ }^{111}$

\footnotetext{
101 FGrH 239 ep. 30.

102 Ephoros F 149, 173.

103 According to Simonides, Lykourgos was the brother of Eunomos, not his son (Plut. Lyc. 1; Schol.

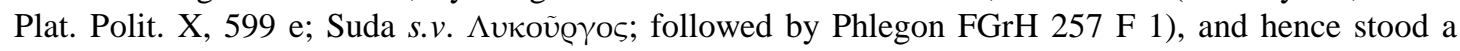
generation higher than according to the "orthodox" stemma.

104 FGrH 566 F 125, with Jacoby’s commentary.

105 Eratosthenes FGrH 241 F 1 and Apollodoros 244 F 61.

106 These 299 or 300 years were probably intended to mark 9 generations $(9 \times 331 / 3=300)$, exactly as is to be expected, since the 11th generation from Herakles was inevitably the 10th from the Trojan war, and hence separated from the fall of Troy by 9 full generations. In Marmor Parium the fall of Troy was dated to the year $1209 \mathrm{BC}$, that is, 314 years before Pheidon. And there is a gap of 314 years between the Eratosthenean-Apollodorean date for the Trojan fall (1183 BC) and the probable Ephorean one for the beginning of the Lykourgan generation (869 BC; $1184-869=314$ ). These 314 years could have been 9 generations of 35 years $(9 \times 35=315)$. (But see Laqueur (n. 87), 527, who demonstrated that, at least in some cases, Marmor Parium was based on a chronological system that counted in generations of 33.3 years. Perhaps we must suggest that the Parian chronicle combined dates deriving from different systems - see Jacoby, FGrH II D, 1930, 669-670.)

107 According to Theopompos (n. 99), Karanos was Pheidon's son, according to Synkellos $(373,498)$ his brother.

108 Vell. Paterc. I, 6.

109 Euseb. Chron. II, 75 Schoene.

110 See n. 12.

111 Arist. fr. 533 Rose; Hieron. ap. Athen. XIV, 635; Phlegon FGrH 257 F 1; Paus. V, 4, 5-6.
} 
And there is one more indication of this synchronisation. Kastor of Rhodos synchronised Lykourgan legislation with the reign of the last Assyrian king Sardanapallos. ${ }^{112}$ We do not know exactly how he dated Sardanapallos. But he probably followed the chronology of Ktesias.113 Ktesian absolute dates for the Assyrian and the Median kings are again uncertain. ${ }^{114}$ But if we are right in assuming that Ktesias assigned the last Median king Astyages a reign of the same duration as did Herodotos, 115 then he (and Kastor following him) must have dated Sardanapallos from 896 to 887 BC. ${ }^{116}$ In this case the Parian date of Pheidon (895 BC) coincides almost exactly with the Ktesian date of the first year of Sardanapallos (896 BC). Again we can see that a crucial event in Asian history - this time the beginning, not the end, of Sardanapallos' reign - was apparently synchronised with both Pheidon and Lykourgos. Indeed, the Parian date of Pheidon may well have been calculated according to the Ktesian chronology. ${ }^{117}$

In view of what has been stated, it is no surprise to find that Pheidon's dating to 797 BC in Eusebios' chronicle was also based on a synchronisation with Lykourgos. In the Canon of Eusebios, the Spartan Alkamenes and the Macedonian Karanos were presented as contemporaries - both began their rule in the year of Abr. 1204 (813 BC). ${ }^{118}$ In the 18th year of Alkamenes, which should have been Abr. 1221 (796 BC) in Eusebios' counting, ${ }^{119}$ he noted the legislation of Lykourgos. ${ }^{120}$ The mention of the introduction of measures and weights by Pheidon appears in the preceding year - Abr. 1220 (797 BC).

All these cases demonstrate that the synchronisation of Pheidon (and Karanos) with Lykourgan legislation was a basic assumption of the ancient chronographers. The synchronisation was dated in two basically different ways. Proceeding from the standard Lykourgan genealogy, it led to the 6th and 7th generations from Temenos. In this way Theopompos and the Parian chronicler achieved their datings. Alternatively, it was possible to proceed from the assumption that Lykourgos was active by the establishment of the first Olympic games, ${ }^{121}$ which could in turn have been reconciled with the Ephorean version that Pheidon was the 10th from Temenos and a

\footnotetext{
112 FGrH 250 F 1d, 37.

113 Schwartz (n. 14), 9; Jacoby FGrH II D 1930, 818-819; Mosshammer (n. 14), 182.

114 Ktesian dates could be arrived at by counting the durations he gives for the reigns of the Median kings (Diod. II, 32. 4-34. 6 = FGrH 668 F 5) back from the traditional date of Astyages' fall, 560 BC. But we do not know how many years Ktesias attributed to Astyages.

115 That is, 35 years - Hdt. I, 130.

116 Mosshammer (n. 14), 182 contra Schwartz (n. 14), 6-9 and Jacoby FGrH II D, 1930, 818-819, who suggested that Ktesias (and Kastor) had assigned Astyages only one year, in which case Sardanapallos should be dated to $882-863 \mathrm{BC}$.

117 That the synchronisation of the Assyrian fall, Lykourgos and Karanos (Pheidon) was based on Ktesian counting was suggested by Busolt (n. 7), 616-617. There are reasonable grounds for suggesting that Timaios' date for the fall of Troy (1194 BC), the Ktesian date for Sardanapallos (896 BC) and the Parian date for Pheidon (895 BC), the last two about 300 years after the first, exactly when we should expect Lykourgos (who was dated 299 years after the fall of Troy by Eratosthenes and Apollodoros - see above), were intentionally fitted together to form a coherent chronology.

118 Euseb. Chron. II, 75 Schoene.

119 The statement actually appears two years too late, at Abr. 1223 (794 BC), that is, in the 20th year of Alkamenes.

120 Euseb. Chron. II, 76 Schoene.

121 See n. 111.
} 
contemporary of the Spartan Alkamenes. ${ }^{122}$ Such considerations led to Pheidon's dates in Eusebios and Isidorus. ${ }^{123}$

The reason for the synchronisation of Pheidon and Lykourgos is not entirely clear. The Lykourgan legislation that marked the beginning of Spartan eunomia was certainly an epochal event for the Greeks. It is not at all strange that it was synchronised with an equally important event in Asian history - the fall of Assyria and the rise of Media. And when the Macedonian kings were anxious to provide themselves with an old and respectable pedigree, it was quite natural to attach their supposed forefather Karanos to this synchronisation. The synchronisation of Karanos' father or brother Pheidon with Lykourgos would have been, in this case, a mere byproduct of the Macedonian propaganda.

On the other hand, the ancients used to compare the early histories of the Dorian states in Peloponnesos. The emergence of the well-ordered and prosperous Sparta was contrasted with the decline of the other states: the destruction of Messenia and the weakening of the previously dominant Argos. ${ }^{124}$ Lykourgos and Pheidon must have been considered crucial figures in this process - the first as the wise and virtuous architect of Spartan eunomia and the second as the king whose excessive ambitions led to sacrilegious acts and the downfall of his previous hegemony. Plato was quite explicit about the tyrannical behaviour of the Messenian and Argive kings being the cause of the decline of these states, while pointing out that similar development in Sparta was checked by Lykourgos. ${ }^{125}$ A similar approach was probably taken by

122 According to Diodoros (VII, 8) the first Olympic games took place in the 10th year of Alkamenes. Indeed, Jacoby (n. 7), 122-127 suggested that the 18th year of Alkamenes, in which Eusebios dated Lykourgos (and, we can add, Pheidon), was nothing other than a distorted variant of this 10th year. This may or may not be so (for different explanations of the reason for dating Lykourgos to Alkamenes' 18th year see Schwartz (n. 14), 64-65; Kiechle (n. 81), 227-232; Mosshammer (n. 14), 188-189), but an eventual synchronisation of the first Olympic games and the reign of Alkamenes is still certain. This synchronisation was not followed by Ephoros, in whose reckoning Alkamenes (as the 10th from Aristodemos) must have begun his rule ca. $770 \mathrm{BC}$, nor in the Canon of Eusebios, where the first Olympic games were synchronised with the end of Alkamenes' reign. We can see here the events dated according to the three different chronologies considered above - the Canon of Eusebios representing the high, Diodoros the middle and Ephoros the low chronology. The Canon, dating the beginning of the Spartan Agiad stemma to 1102 BC instead of Ephoros' 1069 BC, differed from Ephoros in dating the whole sequence, including Alkamenes, about a generation higher (see n. 72).

123 Possibly, the synchronisation of Pheidon with Ol.1 formed a part of the high chronology considered above. We have demonstrated that Ol.1 stood, in the high chronology, logically in the same position as Pheidon's anolympiad (Ol.8) in the low chronology - both were synchronised with the end of the Corinthian kingship and supposed to have been followed by the outbreak of the first Messenian war. We have also noted that this chronology was connected with the Apollodorean (Eratosthenean) date of the Herakleid invasion. Now, we know that Lykourgos was already dated to Ol.1 by Aristotle (fr. 533 Rose). And at roughly the same time Theopompos considered Pheidon as Lykourgos' contemporary. A little later Timaios postulated the existence of two Lykourgos, one at the time of Homer and the other at the time of the first Olympic games (FGrH 566 F 127). It was not at all strange that Pheidon was, thereafter, associated with the second Lykourgos and dated accordingly to the time of the first Olympic games. Naturally, it must have brought about the same dating of the events he was synchronised with (the end of the Corinthian kingship and the outbreak of the Messenian war). This synchronisation could have been a part of the chronology of Eratosthenes and Apollodoros from the very moment of the creation of their system. Sosibios, however, continued to rely on Ephorean datings and did not admit the synchronisation of Lykourgos and Pheidon.

124 Isokrates, Archid. 17-23; Panath. 177f; Plato, Nom. 683f. This scheme was probably followed by Ephoros as well (A.Andrewes, Ephoros book I and the kings of Argos, CQ 45, 1951, 39-42).

125 Plato, Nom. 690d-692b. 
Aristotle, who mentioned Pheidon as a king who had turned his kingship into a tyranny by overstepping the bounds of traditional royal power, and spoke also of the tyranny of Charillos at Sparta before Lykourgan legislation. ${ }^{126}$ All this could have made the assumption of the approximate contemporaneity of Pheidon and Lykourgos quite acceptable to the ancients ${ }^{127}$ and, though we have no evidence that they were ever explicitly connected with each other (except in the chronological systems), could nevertheless have given either Theopompos or someone else working on Macedonian history sufficient grounds for dating Pheidon and with him the beginning of the Macedonian dynasty to the time of Lykourgos.

\section{Conclusion}

Thus, all the datings that the ancients proposed for Pheidon (with the exception of what was suggested by Herodotos) were calculated according to one of two basic synchronisations. First, when Ephoros dated Pheidon to the 10th generation from Temenos, he synchronised him with the end of the Corinthian kingship (indeed, he let him perish in the strife connected with this event) and with the Spartan kings of the first Messenian war. This was further supplemented by the story of Aktaion, which connected Pheidon with the foundation of Syracuse, and by the fact that what was known about the poet Eumelos provided a chronological link between the Corinthian colonisation and the outbreak of the Messenian war. The result was that Pheidon was synchronised with the founder of Syracuse, Archias, the last Corinthian king Telestes and the epic poet Eumelos, and that the first Messenian war was considered to have broken out immediately after the collapse of Pheidon's hegemony. On this set of synchronisations was based the date 748 BC by Pausanias, probably deriving from the chronology of Sosibios that was, in turn, based on Ephoros' genealogical computation. Second, the references in Theopompos and Marmor Parium on Pheidon as Temenos' 6th or 7th descendant, and the exact dates in the Parian chronicle (895 BC), in Eusebios (797 BC) and in Isidorus (776 BC) were based on the assumption that Pheidon was a contemporary of the Spartan lawgiver Lykourgos.

None of this gives any definite answer about Pheidon's real date. Everything depends on how much respect one has for the assumptions the ancients relied on. But at least it should make us rather sceptical about attempts to discover the exact date of Pheidon's Olympic intervention based on the authentic Olympian chronicle and connected with the Pisatan agonothesia in the seventh century BC. And, above all, it reveals the considerations that compelled the ancients to ignore the dating suggested by Herodotos and to date Pheidon instead to what we call the very beginning of the Archaic era.

\footnotetext{
126 Arist. Pol. 1310b 26-27, 1316a 33-34.

127 Aristotle, dating Lykourgos to the time of the first Olympic games in 776 BC (fr. 533 Rose), placed him very close to the Ephorean generation of Pheidon.
} 